\title{
Regional Economic Integration in the Southern African Development Community (SADC): Analysing the Dynamics and Performance
}

\author{
J. Muntschick \\ Johannes Gutenberg-University, Mainz, Germany
}

\begin{abstract}
This article analyses the dynamics and performance of regional economic integration in the Southern African Development Community (SADC). It proposes an innovative theoretical approach to the analysis of regionalism that refers to cooperation theory and takes the impact of external actors explicitly into account. The motivation for this research stems from the observation of a new wave of regionalism in the Global South. Many of these new or reformed regional integration organisations (RIOs) comprise of developing countries, particularly in Africa. In contrast to expectations of most mainstream integration theories, new regionalisms in the Southern Hemisphere have come into existence and show considerable degrees of dynamics and institutional performance. However, there is evidence that regionalisms in the Global South are less stable than in the North and not always entirely under control of regional actors only. This puzzling observation, of which the SADC gives an example, has motivated research for this article. Its central aim is to explain the recent integration dynamics and performance of the organisation in its key policy area, namely the economy. By applying a situation-structural approach to analyse and explain the development of institutionalised regional integration, the author argues that patterns of strong and asymmetric interdependence between regional and extra-regional actors may have an ambivalent impact on the genuine structure of regional cooperation problems, institution-building and institutional performance. The article illustrates and explains this on the example of SADC's key economic integration projects: the SADC Free Trade Area and the scheduled SADC Customs Union.

Key words: regionalism, regional integration, external influence, Southern African Development Community (SADC), European Union (EU), Africa, trade

Acknowledgements: No funding involved. Parts of the research in this article have been published by the author in other works.

For citation: Muntschick, J. (2020). Regional Economic Integration in the Southern African Development Community (SADC): Analysing the Dynamics and Performance. Vestnik RUDN. International Relations, 20 (2), 333-346. DOI: $10.22363 / 2313-0660-2020-20-2-333-346$
\end{abstract}

Научная статья

\section{Региональная экономическая интеграция в Сообществе развития Юга Африки (САДК): анализ динамики и результатов}

\author{
Й. Мунтшик \\ Майнцский университет им. Иоганна Гутенберга, Майнц, Германия
}

\begin{abstract}
В статье анализируется динамика и показатели региональной экономической интеграции в Сообществе развития юга Африки (САДК). Предлагается инновационный теоретический подход к анализу регионализма, который основывается на теории сотрудничества и в полной мере учитывает влияние внешних акторов. Актуальность данного исследования обусловлена развитием новой волны регионализма на Глобальном Юге. Многие из этих
\end{abstract}

(C) Muntschick J., 2020

This work is licensed under a Creative Commons Attribution 4.0 International License.

https://creativecommons.org/licenses/by/4.0/ 
новых или реформированных региональных интеграционных организаций (РИО) включают развивающиеся страны, особенно в Африке. В отличие от ожиданий большинства основных интеграционных теорий в Южном полушарии появились новые региональные интеграционные группировки, которые демонстрируют значительную динамику и институциональную эффективность. Тем не менее есть свидетельства того, что регионализм на Глобальном Юге менее стабилен, чем на Севере, и не всегда полностью находится под контролем только региональных акторов. Это удивительное наблюдение, примером которого является САДК, послужило стимулом для написания данной статьи. Ее главная цель - объяснить недавнюю интеграционную динамику и эффективность организации в рамках ключевого направления деятельности, а именно в экономике. Применяя ситуационноструктурный подход для анализа динамики институтов региональной интеграции, автор утверждает, что существенная и асимметричная взаимозависимость между региональными и внерегиональными акторами оказывает двойственное влияние на архитектуру регионального сотрудничества и институциональную эффективность. В статье это иллюстрируется на примере ключевых проектов экономической интеграции САДК: зоны свободной торговли САДК и Южноафриканского таможенного союза.

Ключевые слова: регионализм, региональная интеграция, внешнее влияние, Сообщество развития Юга Африки (САДК), Европейский союз (ЕС), Африка, торговля

Благодарности: Финансирование не привлекалось. Части данной статьи ранее были опубликованы автором в других работах.

Для цитирования: Muntschick J. Regional Economic Integration in the Southern African Development Community (SADC): Analysing the Dynamics and Performance // Вестник Российского университета дружбы народов. Серия: Международные отношения. 2020. Т. 20. № 2. C. 333-346. DOI: 10.22363/2313-0660-2020$20-2-333-346$

Since the end of the Cold War a wave of new regionalism [Hettne, Söderbaum 1998] can be observed in various parts of the globe. Many of these new regional integration organisations (RIOs) were founded or reformed in the early 1990s and put a focus on economic block-building and security cooperation. Well-known examples include the Association of Southeast Asian Nations (ASEAN), the Economic Community of West African States (ECOWAS), the Common Market of the South (MERCOSUR) and the Southern African Development Community (SADC). On the part of the member states, engaging in regional integration and joining RIOs can be a strategy to better cope with the challenges of globalisation, to reap benefits of intraregional economic interdependence, to respond to geopolitical insecurity, and to foster socioeconomic development and political stability [Mattli 1999]. The European Union (EU) is probably the best example, and for some a role model, of successful regionalism - despite the recent crises and Brexit [Börzel, Risse 2009].

From a plain politico-economic perspective, it is quite puzzling that many of these new regionalisms emerged in the Global South ${ }^{1}$. In

1 In a rather broad understanding, the Global South shall stand for the regions with mostly non-industrialised, developing countries in the Southern Hemisphere. contrast to regions with economically highly interdependent and industrialised countries like Europe, North America and parts of Eurasia, regional integration organisations in the Southern Hemisphere comprise mostly of developing and economically less interdependent countries with comparably strong (economic) relations to extraregional actors. For these reasons are the preconditions for successful integration dynamics and well-performing regionalisms for structural reasons allegedly rather unfavourable - at least according to mainstream integration theories [Haas 1958; Mattli 1999; Moravcsik 1998].

Nonetheless, regionalism in the Global South has come into existence and many RIOs have shown considerable integration dynamics in a variety of policy areas. However, empirical evidence suggests that the dynamics and performance of regionalism in the Global South are not sufficiently stable and not always entirely under control of regional actors only [Doidge 2011; Muntschick 2013]. This is particularly the case in SADC, which is one of the most realistic and promising RIOs in Africa and one of the eight officially recognised regional economic communities (RECs) that count as buildingblocks for wider African integration ${ }^{2}$. The

2 Regional Economic Communities (RECs) // African Union. URL: https://au.int/en/organs/recs (accessed: 17.03.2020). 
SADC's key objectives are to foster socioeconomic development, peace and security and improve the living conditions of its peoples by means of regional cooperation in a broad range of policy areas, particularly the economy ${ }^{3}$. While there is evidence for institutional dynamics and success with regard to the SADC Free Trade Area (SADC FTA), there are also signs of failure as the envisaged SADC customs union exemplifies [Muntschick 2018].

This article aims to illustrate and explain the recent integration dynamics and performance of the organisation in its key policy area. Given the fact that South African counts as regional hegemon and that SADC as an organisation is heavily dependent on the EU as largest donor [Amos 2010; Stapel, Söderbaum 2019], scrutinising the role and impact of regional and extraregional actors shall be part of the analysis. Since the SADC represents a prime example of the new regionalism in the Global South, insights on this illustrative single case study could contribute to a better understanding of integration dynamics and the performance of RIOs in the Southern Hemisphere and beyond.

So far, the scientific debate on how to analyse and explain regionalism, regional integration processes and outcomes is yet significantly influenced by research on the EU. Theory-driven and systematic empirical studies on similar phenomena and observations beyond Europe are yet rare to find. This implies that research on regionalism in the Global South is often inherently Euro-centric. Much of the research on regionalism outside Europe, including the SADC, is done by experts from the field of area studies. These works are in general very rich in empirical content but often not theory-informed and rather descriptive [Mair, Peters-Berries 2001]. Shortcomings are specifically evident with regard to the lack of literature on the performance of regionalism beyond the EU. Extra-regional relations and the influence of external actors on regional integration processes and institutional performance have only recently gained the attention of scholars doing research on regionalism [Muntschick 2018; Plank 2017].

\footnotetext{
${ }^{3}$ SADC Objectives // SADC. URL: https://www.sadc.int/ about-sadc/overview/sadc-objectiv (accessed: 17.03.2020).
}

The main part of this article starts with a theory-informed explanation of the logic of regional integration dynamics and provides a brief conceptualisation of institutional performance. Taken this into account, the empirical part will provide a theory-informed analysis of regionalism in the SADC, namely in the key policy area of the economy. Major insights and an overall assessment form the conclusion.

\section{Theorising Regional Integration Dynamics and Institutional Performance}

Scholars of international relations understand regions often as macro-regions that are supranational subsystems within the international system, whose constituents are states that are geographically close and share some degree of interdependence [Nye 1968: 7]. Following this view, regionalism can be conceptualised as planned, multilateral, and state-led organisation of interdependence within a confined regional space that manifests in various specific regional projects and accompanying institutions [Bach 2003: 22]. In other words, regionalism can be understood as cluster of various, multidimensional regional cooperation projects bounded by a territorial dimension confined by its member states.

The incentive for international cooperation originates from the structure of the international system and underlying cooperation and collective action problems, which emerge in the context of complex interdependence [Keohane 1984: 51]. If actors follow plainly egocentric and uncoordinated strategies, such a pattern of interdependence within any issue-area almost inevitably produces policy externalities for all others involved. Therefore, utility-maximising actors have incentives to seek mutual cooperation in specific problematic situations [Axelrod, Keohane 1985]. Policies aiming for coordination and cooperation - depending on the prevailing situation - may help to achieve Pareto-superior outcomes for all actors provided that the expected benefits surpass the payoffs of an uncoordinated status quo [Zürn 1987: 9-10].

To achieve this goal, states have incentives to institutionalise cooperation - even if that 
involves certain financial or political costs. International institutions are so useful because they help to "lock-in" international cooperation. Their regulative and "civilising" elements facilitate not only international cooperation but increase collective and country-specific welfare and contribute to a stable and peaceful international environment. In the context of the Global South, functional and well-performing international - or regional — institutions may ideally contribute to sustainable development in a broader sense [Zürn 1987: 36, 44-45].

How can we explain regional integration dynamics, which shall be understood as the emergence and design of regional institutions, from a theoretical perspective? How can we explain the role and influence of powerful regional and extra-regional actors?

A cooperation problem on international and regional level can be modelled with the help of game theory [Oye 1985]. Zürn's situation structural approach takes reference to this and distinguishes several ideal types of problematic situations that imply various degrees of conduciveness to cooperation and the formation of common regulative institutions: Cooperation is comparably easy to achieve in problematic situations corresponding to coordination and assurance games while it is more difficult in those resembling to the dilemma-type and most difficult to achieve in suasion games. Taking this theoretical perspective, it depends therefore primarily on the structure of a cooperation problem - or in other words: the type of "game" a problematic situation reminds of - as to what degree international cooperation is likely, how strong the demand for regulative institutions will be, and how relevant potential context factors will be [Zürn 1993].

Most scholars agree that the factor power is certainly a most relevant and pivotal context factor - not only in the context of analysing regional/international institutions but also with regard to e.g. bargaining theory and the study of international relations in general [Zürn 1993: 70-71]. A country's power position, however, is not only based on its overall economic and military capacity but particularly on situation-specific determinants. According to intergovernmental bargaining theory, a state's (bargaining) power position depends on the character of overall - and particularly issue-area specific - asymmetric interdependence between all actors involved.

A country is in a weak power position if it appears to be very dependent on a cooperative agreement under negotiation and has limited alternative or exit options available. This could be because of strong preference intensity, high individual payoffs, and scarcity or lack of attractive unilateral policy alternatives. On the contrary, a strong or superior power position derives from a country's autonomy or indifference regarding a cooperative agreement under negotiation. This could be because of low preference intensity, limited individual payoffs or the availability of attractive unilateral policy alternatives and plausible exit-options [Keohane, Nye 2001: 9-11; Moravcsik 1998: 60-67].

When it comes to interstate bargaining on regional level, states which are dependent on their counterparts in a certain issue-area and do not have credible exit-options available are likely to be in a comparably weak position. In contrast, states on which their regional counterparts are dependent on are in relatively strong power position. They can become agenda setters and drivers for regional integration dynamics and become thus mainly responsible for the performance of regionalism. Such powerful key countries can foster or inhibit the process of regional integration and may subject their engagement in regional cooperation projects on condition of their weaker regional partners' willingness to compromise [Gehring 1994: 216].

The negotiation outcomes, e.g. the particularities of regional arrangements or the institutional design of regionalism in general, reflect therefore not only the structure of a cooperation problem and the preference constellation of the involved states but also the relative power-position of the negotiators. With power being a key context factor, hegemonic actors such as regional great powers play therefore a pivotal role. They can exert most influence on integration dynamics and the performance [Zürn 1993: 70]. 
One could argue that regional integration in the Global South basically follows the same logic as elsewhere, e.g. in Europe or North America. This is ceteris paribus principally true. However, there are structural differences. In many issue-areas, countries and RIOs in the Southern Hemisphere show substantial patterns of asymmetric extra-regional interdependence to external actors. This is most visible in trade relations but also regarding foreign direct investments (FDI) flows and official donor assistance (ODA). The relational aspect of this asymmetry reflects moreover in unidirectional military aid flows and the presence of external forces in some southern regions. Whether or not this is a legacy of colonialism, this shadowstructure of asymmetric extra-regional interdependence has a significant impact on the integration dynamics and the performance of regionalism in the Global South; and mainstream integration theories have ignored this important structural aspect so far [Young 1969: 727].

External influence by powerful extraregional actors can be conceptualised as context factor similar to power. It can affect the inherent structure of a regional cooperation problem, the bargaining power of regional actors and therefore also the integration dynamics and performance of institutional arrangements in particular and regionalism in general. How can that happen?

Firstly, a shadow-structure of asymmetric interdependence between regional and extraregional actors can shift the genuine structure inherent to a regional cooperation problem towards a more cooperation-aversive situation and thus obstruct a solution. In terms of the situation structural approach, a genuine dilemmatype situation could be transformed into a suasion-type structure. This is the case if actors follow an uncooperative strategy on regional level because they have competing, more rewarding extra-regional policy alternatives. Or in other words: if states prefer to cooperate with promising external parties on the grounds of strong extra-regional relationships instead of engaging in (mutually exclusive) regional integration projects within their less promising regional counterparts [Axline 1994: 26; Muntschick 2012].
Alternatively, however, can extra-regional actors principally also become conducive to regional integration dynamics if they support the solution of regional cooperation problems by e.g. providing side payments, increasing cooperative payoffs etc. [Axline 1994: 24-25]. In terms of the situation structural approach, a genuine dilemma or even suasion-type situation could accordingly be transformed towards a more conducive situation. This can be the case if states outside a region (e.g. important donors) provide external support only on condition that the receiving partners foster regional integration and engage in regional institution building. In an extreme case, regional integration dynamics could thus be entirely fuelled from outside and thus driven by external influence.

Apart from the impact on the structure of regional cooperation problems, external actors may also unfold influence on regional actors' bargaining power in interstate negotiations. This is the case if external actors e.g. strengthen a country's position on regional level by means of direct support or by providing attractive alternative options that are not available to other countries in the region [Sebenius 1983]. Moreover, external actors may enhance the performance of regional institutions by e.g. supporting their capacity and effective functioning by financial or logistical means. This can indeed make a difference if regional actors are unsure about the benefits of regional integration and face initially high costs of regional institution building. In an extreme case, this could even lead to the emergence of façade institutions reminding of Potemkin villages whose sole purpose is to attract an inflow of external donor support [Söderbaum 2004].

As an interim conclusion, while regional hegemons play an important role as potential drivers for regional integration dynamics and certainly key countries for the performance of regionalism, powerful extra-regional actors may have an ambivalent influence in this respect. Since countries and RIOs in the Global South are for mainly economic reasons structurally more prone to external influence compared to their northern counterparts, the performance of regionalisms in the Southern Hemisphere 
depends likewise more on actors and policies outside their own region.

Assessing the institutional performance of regionalism systematically is a fairly complex task. This begins with a debate about the meaning of performance. The international relations literature has a long tradition of studying the performance and effectiveness of international institutions, notably international (environmental) regimes [Underdal 1992; Young 1992]. Many scholars argue that the concept of effectiveness includes several dimensions such as e.g. output, outcome and impact. However, there exists no common understanding or definition of institutional effectiveness or performance yet. In a general and broad understanding, performance is about the fulfilment of tasks. Recent literature evaluating the performance of the EU in international relations referred to effectiveness as attainment of stated or unstated goals [Bergmann, Niemann 2015].

An outcome-oriented conceptualisation of effectiveness is a valuable tool to assesses the institutional performance of an organisation (e.g. a RIO) when referring to its own goals. Certainly, this approach might be limited because it does not explicitly look at impact or because several factors might affect the degree of performance, e.g. the ambitiousness of stated goals. However, conceptualising institutional performance in terms of goal attainment seems to be a practical method to evaluate the success of regionalism - or specific projects thereof due to its focus on the essential. An ordinal scale of institutional performance (e.g. high, medium and low) that refers to the level of goal attainment could be useful to refine and illustrate the empirical findings.

\section{The Southern African Development Community (SADC)}

Founded in 1992, the SADC is the successor of the Southern African Development Coordination Conference (SADCC), which was established by black majority-ruled countries in 1980 in response to destabilising politics by apartheid South Africa. Today, the SADC has 16 member states ${ }^{4}$, covers an area of almost

\footnotetext{
${ }^{4}$ Angola, Botswana, Comoros, Democratic Republic of Congo, Eswatini (Swaziland), Madagascar, Malawi,
}

10 million $\mathrm{km}^{2}$ with a population of about 345 million people ${ }^{5}$. Most member states are classified as low or lower middle-income countries $^{6}$. South Africa counts as the only industrialised country of the SADC. It is an emerging economy and part of the so-called BRICS grouping [Yurtaev 2016]. According to scholars, the SADC is one of the most constant, realistic and promising regionalisms in Africa [Mair, Peters-Berries 2001; Weiland 2006].

\section{The SADC Free Trade Area:}

\section{Driven by South Africa and Performing Well}

Since the mid-1990s, regional economic integration is a key area of the organisation's overall agenda as outlined in the SADC Treaty ${ }^{7}$ and the Regional Indicative Strategic Development Plan (RISDP) ${ }^{8}$. From a plain structural perspective, demand for market integration in SADC countries rooted in the pattern of intra-regional economic interdependence and the prospects for increasing intra-regional trade and, thus, generating absolute welfare gains.

Besides low intra-SADC trade volumes in the 1990s, countries saw a significant potential to increase trade amongst them because comparative cost advantages and informal trade flows existed in the region [Cleary 1999: 7]. Comparative cost advantages were particularly relevant with respect to various agricultural products and foodstuffs, such as e.g. beef (Botswana, Mozambique, and Namibia), beverages (Swaziland), tea and coffee (Malawi and Zimbabwe), tobacco (Angola, Malawi, Tanzania, Zambia, and Zimbabwe), sugar

Mauritius, Mozambique, Namibia, Seychelles, South Africa, United Republic of Tanzania, Zambia, Zimbabwe.

5 SADC Facts \& Figures // SADC. URL: https://www.sadc.int/about-sadc/overview/sadc-factsfigures (accessed: 17.03.2020).

6 World Bank list of economies // The World Bank. June 2019. URL: http://databank.worldbank.org/data/ download/site-content/CLASS.xls (accessed: 17.03.2020).

7 SADC Treaty // SADC. URL: https://www.sadc.int/ documents-publications/sadc-treaty (accessed: 17.03.2020).

${ }^{8}$ Regional Indicative Strategic Development Plan // SADC. URL: https://www.sadc.int/documents-publications/ show/Regional_Indicative_Strategic_Development_Plan. pdf (accessed: 17.03 .2020$)$. 
(Mauritius, South Africa, Swaziland) or cotton (Tanzania). Regarding light manufactures and semi-manufactured goods, Lesotho, Malawi, Mauritius, Mozambique and Zambia had comparative advantages in specific products such as textiles, clothing and furniture.

The only industrialised and diversified economy, South Africa, had much more potential for exploiting comparative cost advantages across various sectors, namely in mechanical engineering and the heavy industry [Valentine 1998: 15-16]. Globalisation fuelled additionally demand in SADC countries for regional economic block-building because a larger common market would attract more FDI from overseas. However, the biggest potential for increasing intra-regional trade was between the developing, agricultural SADC members with their labour-intensive products on the one hand and South Africa as developed, industrialised economy with its capital-intensive goods on the other hand [Qualmann 2003: 141-143].

Looking closer at intra-SADC trade relations reveals a distinct pattern of asymmetric interdependence which allows conclusions on the power structure among SADC members. In the mid-1990s, more than half of SADC members traded more with other SADC countries than external actors. The SADC market was a major or even the top trading destination for Botswana, Lesotho, Malawi, Mozambique, Namibia, Swaziland, Zambia and Zimbabwe in the year 1995. In terms of exports (as \% of total exports), the SADC region was the top destination for Swaziland (53\%), Lesotho (45\%), Namibia (30\%), and very important for Mozambique (30\%), Zimbabwe (30\%) and Botswana (25\%) in the same year [Muntschick 2018: 109].

Moreover, most SADC member states were heavily dependent on South African FDI at that time [Grobbelaar 2004: 93-95]. This monocentric pattern of intra-regional economic relations put South Africa not only in the position of an economic hub on regional level but also in relative power position. This is because South Africa was not as heavily dependent on the SADC region as trade and particularly export destination compared to most of its regional counterparts. In 1995 , only $10 \%$ of South Africa's total exports shipped to destinations within the SADC. Nevertheless, Pretoria valued the region as its "backyard" for selling much of those manufactured goods that could not compete in global markets [Muntschick 2018: 109].

The cooperation problem related to mutual trade liberalisation among states on a regional level can be interpreted as a dilemma-type situation. All SADC states could generate absolute welfare effects by mutual tariff reductions if everyone sticks to the rules and does not engage in free-riding. This resulted in the demand for institutionalised cooperation in form of a SADC Free Trade Area (FTA) and led to the negotiation and adoption of the SADC Protocol on Trade in $1996 / 2000^{9}$. Tough bargaining concerned the legislative design of the Protocol, notably the time schedule, the basket of goods, the Rules of Origin (RoO), and specifications on sensitive goods. South Africa played a key role in many respects. The country was not only the agenda-setter and most committed driver of the project but as well as the most assertive country in terms of drawing up rules and provisions [Muntschick 2017: 187]. This reflects particularly in the restrictive RoO which have not least been designed to protect the South African economy from intra-SADC competition as e.g. in the textile and garments sector [Flatters 2004: 55].

External actors did not unfold any significant impact on the institutionalisation of the SADC FTA. Certainly, the EU supported policies of regional economic integration in southern Africa with several million Euros via various policy instruments and mechanisms [Tjønneland 2006]. However, there is little concrete evidence whether and how this had any specific effects; if any, they were most likely supportive to the project.

The implementation of the SADC Protocol on Trade by most of the organisation's member states led to the creation of the SADC FTA in August 2008. This meant that $85 \%$ of total intra-

\footnotetext{
9 Protocol on Trade in SADC Region 1996 // SADC. URL: https://www.sadc.int/files/4613/5292/8370/Protocol on_Trade1996.pdf (accessed: 17.03.2020).
} 
regional trade was officially free of customs. However, maximum tariff liberalisation was only attained by January 2012, when the tariff phase down process for sensitive products was completed $^{10}$. This seems to be a big success at least on paper. Looking closer on the performance of SADC's flagship project in terms of goal attainment gives a slightly different picture. The key objective of the SADC FTA is to eliminate barriers to intra-regional trade as stated in articles 2 and 3 of the Protocol on Trade $^{11}$. This implies that increasing intra-SADC trade is not only the main goal of regional economic integration in SADC but also the main benchmark for assessing its success.

There is evidence that the regional trade liberalisation and the institutionalisation of the SADC FTA have contributed to increasing intraregional trade. While the intra-regional tradeshare oscillated only between $9-15 \%$ in the mid- to late-1990s [Muntschick 2018: 131], it has grown to more than $20 \%$ in the following two decades as the Figure 1 illustrates.
Most significant is the increase in intraregional exports. While SADC member states exported only $14.1 \%$ of their total exports to the SADC region in 2001, this figure rose to $23.8 \%$ in 2019. This is an increase of almost $70 \%$ in less than 20 years - and the overall trend seems to be promising despite some backlashes because of the global financial crisis 2007-2008. It indicates that the SADC region has increasingly become a more important export destination for SADC members over the years. The share of intra-SADC imports, in contrast, has not much changed throughout the past two decades. Additional research is needed to explain this very recent drop from $19.5 \%$ to $12.5 \%$ in 2019 .

In general, intra-regional trade shares would possibly be much higher today if all member states adhered to the Protocol on Trade and their tariff commitments. Malawi, Tanzania and particularly Zimbabwe, however, fell behind the schedule in the past and experienced implementation problems - or showed reluctance - in phasing-down tariffs ${ }^{12}$. This led

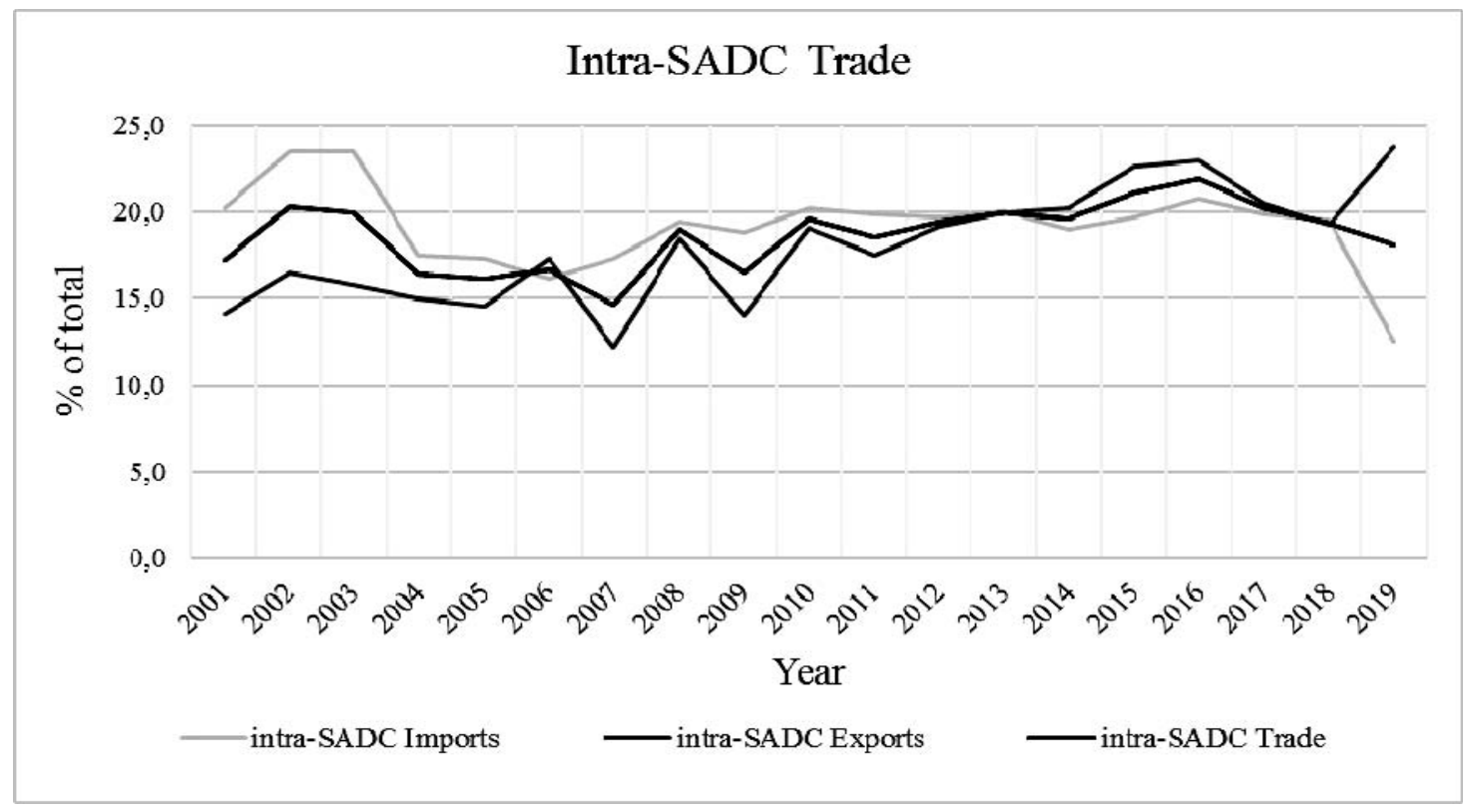

Fig. 1. Intra-regional Trade Shares in the SADC (2001-2019) ${ }^{13}$

Source: designed by the author.

\footnotetext{
${ }^{10}$ Free Trade Area // SADC. URL: https://www.sadc.int about-sadc/integration-milestones/free-trade-area (accessed: 17.03.2020).

11 Protocol on Trade in SADC Region 1996 // SADC. URL: https:/www.sadc.int/files/4613/5292/8370/Protocol on_Trade1996.pdf (accessed: 17.03.2020).
}

\footnotetext{
${ }^{12}$ Free Trade Area // SADC. URL: https://www.sadc.int/ about-sadc/integration-milestones/free-trade-area (accessed: 17.03.2020).

${ }^{13}$ Intra-regional trade shares in the SADC (2001-2019) // TradeMap. URL https://www.trademap.org (accessed: 17.03.2020).
} 
to several derogations and certainly impeded the overall performance of the SADC FTA. The same applies for non-tariff barriers to trade which include inter alia import quotas, customs delays, infrastructure or other technical barriers that put obstacles to free trade. The SADC introduced a mechanism for identifying, reporting and removing non-tariff barriers in 2005. This created certainly awareness of the problem and contributed to solutions in individual cases. However, sanitary and phytosanitary measures as well as technical barriers remain the most common non-tariff barriers to trade in the SADC region so far $^{14}$.

\section{The SADC Customs Union: Mission Impossible Undermined by the EU}

As a next step to deepen regional economic integration, the SADC envisaged the creation of a customs union (CU). The RISDP mentioned this project explicitly and scheduled the formation of the SADC CU for the year $2010^{15}$. Member states leaders and SADC officials articulated repeatedly demand for a regional customs union as they shared the belief that such an institution would further increase intraregional trade, attract more FDI inflows from overseas and contribute to socio-economic development on national and regional levels ${ }^{16}$.

At first sight, the regional cooperation problem was virtually the same as in the upfront of the creation of the SADC FTA. The pattern of intra-regional economic interdependence in the year 2007 was similar to the one in the mid-1990s: a "hub-and-spoke" pattern with South Africa - as regional economic powerhouse and most important regional trading partner - in the centre [Muntschick 2012]. The SADC member countries' extra-regional trade

\footnotetext{
${ }^{14}$ Non-Tariff Barriers // SADC. URL: https://www.sadc. int/themes/economic-development/trade/non-tariff-barriers (accessed: 17.03.2020).

${ }^{15}$ Customs Union // SADC. URL: https://www.sadc.int/ about-sadc/integration-milestones/customs-union (accessed: 17.03.2020).

${ }^{16}$ SADC pushes towards Customs Union // SA News. August 18, 2010. URL: https://www.sanews.gov.za/southafrica/sadc-pushes-towards-customs-union (accessed: 17.03.2020).
}

relations, which became a crucial factor for the future of the planned customs union, revealed a second pattern of asymmetric interdependence.

The EU was the most important trading partner for the SADC region and about half of the organisation's member states. In terms of exports (as \% of total exports), Botswana (68\%), the DRC (54\%), Madagascar (63\%), Mauritius (70\%), the Seychelles (54\%), South Africa $(33 \%)$ and even Namibia (45\%) traded more with the EU as an extra-regional actor than with their regional counter parts in 2007 [Muntschick 2018: 155]. The dependence of several SADC countries on the European market is clear; albeit the composition of the individual countries' export baskets of commodities traded with the EU were different [Keck, Piermartini 2008: 9294]. Since the SADC region was a rather negligible export destination for the EU's overall exports (only about $3 \%$ in 2007), Brussels was for structural reasons in a relative power position vis-à-vis the SACD countries — including South Africa - in this issue area.

For many years, the EU supported regional economic integration in SADC directly and lastingly with various financial instrument. The EU was the most important external donor to the organisation. The 10th European Development Fund (EDF), for example, provided 116 million EUR for the SADC region of which 85 million EUR were earmarked for regional economic integration ${ }^{17}$. However, there was not only support. The EU changed its trade policy towards SADC after the turn of the millennium. This was because Brussels had to adjust its trade relations with the group of African, Caribbean, and Pacific (ACP) countries after the non-reciprocal Lomé Convention had been replaced by the Cotonou Agreement in the year 2000. The latter was consistent with World Trade Organisation (WTO) standards which demanded that preferential market access may only be granted on the basis of reciprocity [Keck, Piermartini 2008: 86].

17 Regional Strategy Paper and regional Indicative Programme 2008 - 2013 // EU. URL: https://eeas.europa.eu/ sites/eeas/files/rsp_and_rip_2008_2013 en.pdf (accessed: 17.03.2020). 
Against this background, Brussels offered SADC countries to conclude so-called Economic Partnership Agreements (EPAs). These were mainly schemes for a free trade area. However, they also comprised significant developmental and aid-for-trade components. They were included to cushion potentially (negative) effects related to mutual trade liberalisation and adaptation in the southern countries. The embedded development aid component made the EPAs also financially very attractive from a developing country's point of view. More "persuasive", however, was the fact that Brussels ultimately demanded all SADC countries that did not qualify for trading under the duty- and quotafree conditions of the "Everything-But-Arms" (EBA) initiative to negotiate and conclude EPAs as soon as possible in order to maintain preferred access to the EU's common market [Bilal, Stevens 2009]. Brussels repeatedly set ultimatums for SADC countries to conclude full EPAs and threatened to exclude them from preferential market access, which would have caused devastating economic effects in several SADC countries due to their heavy export dependency on the $\mathrm{EU}^{18}$.

The EU's pressure on SADC countries to conclude the EPAs, which were in fact NorthSouth trade regimes, regardless of SADC's agenda to establish a common customs union had an interfering effect on the organisation's economic integration dynamics. To form and implement a complete SADC CU, however, all member countries would firstly need to agree on a common external tariff, secondly implement this to institutionalise an operating customs union, and thirdly act towards third countries as one single actor (same as e.g. the EU did in the Brexit talks). However, none of this happened. Due to the pattern of extra-regional trade dependence of several SADC countries on the EU in combination with Brussels' pressure for concluding EPAs, the structure of the genuine regional cooperation problem of forming a

18 Pressure as EU issues new trade ultimatum // Bilaterals.org. September 8, 2014. URL: https://bilaterals. org/?pressure-as-eu-issues-new-trade\&lang=en (accessed: 17.03.2020).
SADC customs union changed. External influence transformed it towards a cooperationaverse situation which reminded of a suasion game.

This is firstly because the EU did not show any consideration towards SADC's regional economic integration agenda and the scheduled SADC CU. Moreover, Brussels refused the idea to offer all SADC member countries a single and encompassing EPA with the same (favourable) EPA conditions. This is because the EU notably some of its southern member states feared competition from several SADC economies (notably South Africa), particularly in the agricultural sector, and wanted to frame the EPAs according to her own needs and the level of development in the partner countries. This led secondly to a fragmentation of SADC, meaning that several SADC countries joined together in different EPA-groupings in order to negotiate the best EPA-deal with the EU based on the composition of their export baskets and terms of trade. Thus, those SADC countries that needed/preferred to conclude EPAs for economic reasons and expected more benefits from extraregional cooperation with the EU than from deepening economic integration towards a SADC CU became "regional Rambos" [Muntschick 2013: 700].

When Brussels raised diplomatic pressure in the mid-2000 years [Bilal, Stevens 2009], the SADC member states split into four different EPA-groupings. Besides the so-called SADCEPA grouping (which in fact consisted then only of Angola, Botswana, Lesotho, Mozambique, Namibia, Swaziland and South Africa) did other SADC countries join together within the frameworks of the Eastern and Southern Africa (ESA)-EPA grouping (including Madagascar, Malawi, Mauritius, the Seychelles, Zambia and Zimbabwe), the East African Community (EAC)-EPA grouping (including Tanzania) and the Economic and Monetary Community of Central Africa (CEMAC)-EPA grouping (including the DR Congo). This, of course, put the plans for creating a SADC $\mathrm{CU}$ at risk because there can be no customs union where its members negotiate separate and implement 
different trade regimes with external actors [Muntschick 2017: 196].

Even though many SADC officials and member states' leaders continued an obdurate strategy of upholding the plans to create the SADC CU in the near future ${ }^{19}$, the reality check talks a different language. With the stated goal to create a customs union by 2010 , SADC's degree of goal attainment and the institutional performance in its second grand project of regional economic integration is non-existent.

This is because the divide of SADC became even more cemented when its member states in the different EPA-groupings made progress in the negotiations with the EU and started to initialise so-called interim-EPAs, which were labelled as of provisional character. But there is doubt: Brussels' carrot-and-stick policy was successful. This reflects in the fact that Madagascar, Mauritius, the Seychelles and Zimbabwe signed an interim ESA-EPA with the EU in August 2009. They have applied it provisionally since May 2012. The Comoros joined in July 2017 and started applying it since February 2019. After the European Parliament gave consent to the arrangement, negotiations to deepen the interim-ESA-EPA towards a full EPA have started in October $2013^{20}$. The EAC-EPA grouping, which includes Tanzania, finalised its negotiations with the EU in October 2014. Some countries have signed the EPA in September 2016 but Tanzania, which enjoys duty- and quota-free EU access under the EU's EBA scheme, has not done so yet ${ }^{21}$. The same applies for the DR Congo as member of the CEMACEPA grouping where negotiations on an interimEPA concluded in December $2007^{22}$.

${ }^{19}$ SADC pushes towards Customs Union // SA News. August 18, 2010. URL: https://www.sanews.gov.za/southafrica/sadc-pushes-towards-customs-union (accessed: 17.03.2020).

20 Eastern and Southern Africa (ESA) // European Commission. URL: https://ec.europa.eu/trade/policy/ countries-and-regions/regions/esa (accessed: 17.03.2020).

21 East African Community (EAC) // European Commission. URL: https://ec.europa.eu/trade/policy/ countries-and-regions/regions/eac (accessed: 17.03.2020).

22 Central Africa // European Commission. URL: https://ec.europa.eu/trade/policy/countries-and-regions/ regions/central-africa (accessed: 17.03.2020).
The SADC EPA, which includes Botswana, Eswatini (formerly known as Swaziland), Namibia, Lesotho, South Africa and Angola (with an option to join), was signed in June 2016 and became fully operational in February $2018^{23}$. It was subject to particularly long and tough negotiations between Brussels and the SADC partner countries. This is because initially the EU refused to grant South Africa the same beneficial trading terms as the rest of the (less developed) countries in the SADC EPA grouping. Brussels argued that South Africa already enjoyed a privileged market access to the EU under the Trade, Development and Cooperation Agreement (TDCA) and should therefore - as emerging economy - not enjoy the trade benefits designated for its economically much weaker neighbouring states.

This policy raised sharp protest in southern Africa, particularly among the members of the centennial Southern African Customs Union $(\mathrm{SACU})^{24}$. They feared the break-up of the ageold SACU if South Africa on the one hand and the rest of SACU-members on the other hand initialised two different trade regimes with the EU [Draper, Khumalo 2009]. Fortunately, particularly from the SACU member states' perspective, this "horror scenario" did not occur. Despite being in a relative power position, Brussels mend its ways and offered the entire SADC grouping one single EPA with harmonised rules, thereby repealing the trade component of the $\mathrm{TDCA}^{25}$. This saved the SACU - but was probably the final coffin nail for the scheduled SADC CU.

\footnotetext{
${ }^{23}$ Southern African Development Community (SADC) // European Commission. URL: https://ec.europa.eu/ trade/policy/countries-and-regions/regions/sadc (accessed: 17.03.2020).

${ }^{24}$ The SACU was founded in 1910 and is the oldest operating customs union in the world. Its members comprise of Botswana, Eswatini (formerly Swaziland), Lesotho, Namibia and South Africa.

${ }^{25}$ Southern African Development Community (SADC) // European Commission. URL: https://ec.europa.eu/trade/ policy/countries-and-regions/regions/sadc 17.03.2020).
} 


\section{Concluding Remarks}

The SADC is one of the most prominent and promising new regionalisms in Africa and the Global South. Its regional integration agenda is ambitious and has a focus on the key areas of the economy, security and infrastructure. In order to foster socio-economic development and overall welfare in the region, member states demanded further steps towards deepening regional economic integration and increasing intraregional trade flows in the mid-1990s. The main objectives were to create a free trade area and thereafter a customs union by the year 2010 .

Economic relations and trade patterns in the SADC region indicate a moderate potential for increasing intra-regional trade flows and revealed that South Africa is a regional hegemon in economic terms. The Cape Republic used its relative power position in the regional negotiations on the Protocol on Trade that led to the institutionalisation of the SADC FTA. Pretoria was particularly assertive regarding the adoption of strict RoO. The latter protect market players in the SADC FTA to a certain degree from the import of goods originating outside the region; which is mainly a protective measure against the mass inflow of cheap products from China that could damage the South African light manufacturing industry.

Thus, the SADC FTA is not only of benefit for the small economies in the SADC region but mainly for South Africa that gained better market access to its "SADC hinterland" and more opportunities to sell there industrial products that are not very competitive on global markets. The performance of the SADC FTA shows rather promising results. Despite the existence of considerable non-tariff barriers to trade, formal intra-regional trade has grown in absolute and relative terms over the past two decades. This applies particularly to the share of intra-SADC exports and shows that the SADC region is increasingly an export destination for the regional market players. Whether this has an impact on socio-economic development, however, is a different question and deserves further research.
The SADC was not successful in further deepening regional economic integration towards the institutionalisation of a common customs union. The structural reason for this failure roots in the pattern of SADC member states' extraregional economic relations. Several SADC countries are heavily depended on the EU as their (most) important export destination. This structural dependency puts the EU, which is also an economic giant on global level, in a relative power position towards the SADC and its member countries. When Brussels changed its trade policy towards the ACP countries and demanded SADC countries to negotiate new trade regimes in form of the EPAs, it was both the inherent development aid component and the threat of exclusion from preferential access to the common EU market that convinced SADC members to engage in EPA talks.

The EU as an external actor had therefore an interfering influence on regional cooperation efforts towards building the SADC CU because several SADC countries joined together in different EPA groupings and started to negotiate different EPAs with Brussels. In other words: the genuine regional cooperation problem transformed into a suasion game because several regional actors saw more benefits in institutionalising extra-regional cooperation with the EU than in further developing an incompatible and possibly less promising SADC CU. With the adoption and implementation of several different EPAs in the past years, the SADC is welladvised to face reality and the fact that it has failed to institutionalise a SADC CU.

The empirical analysis has shown that powerful external actors may have an ambivalent effect on regionalism and regional integration projects in the Global South. Member states in RIOs that show patterns of strong (economic) dependence on extra-regional actor are prone to external influence because they might face incentives to prefer extra-regional cooperation over regional cooperation. This may lead to regional fragmentation if both of such policies are not compatible. The example of the Ukraine, which has been virtually torn between the EU and the Eurasian Economic Union (EEC) over 
preferential trade regimes, is another example of this dilemma - and possibly also of the sometimes ill-considered and uncompromising policies of external actors in powerful positions. The rise of China and its foreign policy and action towards African RIOs and their member states will possibly lead to similar problems and should therefore deserve the attention of political science and academic research in the future.

Received / Поступила в редакцию: 26.03.2020

Accepted / Принята к публикации: 06.05.2020

\section{References / Библиографический список}

Amos, S. (2010). The Role of South Africa in SADC Regional Integration: the Making or Breaking of the Organization. Journal of International Commercial Law and Technology, 5 (03),124-131.

Axelrod, R. \& Keohane, R.O. (1985). Achieving Cooperation under Anarchy: Strategies and Institutions. World Politics, 38 (1), 226-254. DOI: 10.2307/2010357

Axline, W.A. (1994). The Political Economy of Regional Cooperation. Comparative Case Studies. London: Pinter Publishers and Associated University Press.

Bach, D. (2003). New Regionalism as an Alias: Regionalisation through Trans-State Networks. In: Grant, J.A. \& Söderbaum, F. (Eds.). New Regionalism in Africa. Aldershot: Ashgate. P. 21-30.

Bergmann, J. \& Niemann, A. (2015). Mediating International Conflicts: The European Union as an Effective Peacemaker? Journal of Common Market Studies, 53 (05), 957—975. DOI: 10.1111/jcms.12254

Bilal, S. \& Stevens, C. (2009). The Interim Economic Partnership Agreements between the EU and African States. Contents, Challenges and Prospects. Maastricht: European Centre for Development Policy Management (ECDPM).

Börzel, T.A. \& Risse, T. (2009). Diffusing (Inter-)Regionalism. The EU as a Model of Regional Integration. KFG Working Paper. Berlin: KFG "The Transformative Power of Europe".

Cleary, S. (1999). Regional Integration and the Southern African Development Community. Journal of Public and International Affairs, 10 (01), 1-15.

Doidge, M. (2011). The European Union and Interregionalism. Farnham: Ashgate.

Draper, P. \& Khumalo, N. (2009). The Future of the Southern African Customs Union. Trade Negotiations Insights, $8(06), 4-5$.

Flatters, F. (2004). SADC Rules of Origin in Textiles and Garments: Barriers to Regional Trade and Global Integration. In: Commonwealth Secretariat. The Impact of Preferential Rules of Origin in the Textile and Clothing Sector in Africa. London: Commonwealth Secretariat. P. 41-66. DOI: 10.14217/ 9781848598454-3-en

Gehring, T. (1994). Der Beitrag von Institutionen zur Förderung der internationalen Zusammenarbeit. Lehren aus der institutionellen Struktur der Europäischen Gemeinschaft. Zeitschrift für Internationale Beziehungen, 1 (02), $211-242$.

Grobbelaar, N. (2004). Can South African Business Drive Regional Integration on the Continent? South African Journal of International Affairs, 11 (02), 91-106. DOI: 10.1080/10220460409545469

Haas, E.B. (1958). The Uniting of Europe: Political, Social, and Economic Forces 1950-1957. Stanford: Stanford University Press.

Hettne, B. \& Söderbaum, F. (1998). The New Regionalism Approach. Politeia: Journal for Political Science and Public Administration, 17 (03), 5-19.

Keck, A. \& Piermartini, R. (2008). The Impact of Economic Partnership Agreements in Countries of the Southern African Development Community. Journal of African Economies, 17 (01), 85-130. DOI: 10.1093/jae/ejm006

Keohane, R.O. \& Nye, J.S. (2001). Power and Interdependence. New York, London: Longman.

Keohane, R.O. (1984). After Hegemony. Cooperation and Discord in the World Political Economy. Princeton: Princeton University Press.

Mair, S. \& Peters-Berries, C. (2001). Regionale Integration und Kooperation in Afrika südlich der Sahara. EAC, ECOWAS und SADC im Vergleich. Bonn, München: Weltforum Verlag.

Mattli, W. (1999). The Logic of Regional Integration: Europe and Beyond. Cambridge: Cambridge University Press.

Moravcsik, A. (1998). The Choice for Europe: Social Purpose and State Power from Messina to Maastricht. Ithaca: Cornell University Press. 
Muntschick, J. (2012). Theorising Regionalism and External Influence: A Situation-structural Approach. Mainz Papers on International and European Politics, 02, 1-29.

Muntschick, J. (2013). Regionalismus und Externer Einfluss: Stört die Europäische Union die Regionale Marktintegration im südlichen Afrika? Politische Vierteljahresschrift, 54 (04), 686-713.

Muntschick, J. (2017). SADC. Extra-regional Trade Relations Contrain Deeper Market Integration. In: Krapohl, S. (Eds.). Regional Integration in the Global South. External Influence on Economic Cooperation in ASEAN, MERCOSUR and SADC. Cham: Palgrave Macmillan. P. 179-207. DOI: 10.1007/978-3-319-38895-3

Muntschick, J. (2018). Regionalism and External Influence: The Southern African Development Community (SADC) and the ambivalent Impact of the EU on Regional Integration. Cham: Palgrave Macmillan. DOI: 10.1007/9783-319-45330-9

Nye, J.S. (1968). International Regionalism. Boston: Brown and Company.

Oye, K.A. (1985). Explaining Cooperation under Anarchy: Hypotheses and Strategies. World Politics, 38 (01), 1-24. DOI: $10.2307 / 2010349$

Plank, F. (2017). The Effectiveness of Interregional Security Cooperation: Evaluating the Joint Engagement of the EU and the AU in Response to the 2013 Crisis in the Central African Republic. European Security, 26 (04), 485-506. DOI: 10.1080/09662839.2017.1327849

Qualmann, R. (2003). South Africa's Reintegration Into World and Regional Markets. Trade Liberalisation and Emerging Patterns of Specialisation in the Post-Apartheid Era. Leipzig: Universität Leipzig.

Sebenius, J.K. (1983). Negotiation Arithmetic: Adding and Subtracting Issues and Parties. International Organization, 37 (02), 281-316. DOI: 10.1017/S002081830003438X

Söderbaum, F. (2004). Modes of Regional Governance in Africa: Neoliberalism, Sovereignty Boosting, and Shadow Networks. Global Governance, 10 (04), 419 - 436. DOI: 10.1163/19426720-01004004

Stapel, S. \& Söderbaum, F. (2019). Mapping and Problematizing External Funding to the AU and the RECs. In: Engel, U. \& Mattheis, F. (Eds.). The Finances of Regional Organisations in the Global South. London: Routledge.

Tjønneland, E.N. (2006). SADC and Donors - Ideals and Practices. From Gaborone to Paris and Back. Gaborone: Botswana Institute for Development Policy Analysis.

Underdal, A. (1992). The Concept of Regime "Effectiveness". Cooperation and Conflict, 27 (03), 227-240. DOI: $10.1177 / 0010836792027003001$

Valentine, N. (1998). The SADC's Revealed Comparative Advantage in Regional and International Trade. Cape Town: Development Policy Research Unit.

Weiland, H. (2006). The European Union and Southern Africa. Interregionalism between vision and reality. Interregionalism and International Relations. London, New York: Routledge.

Young, O.R. (1969). Interdependencies in World Politics. International Journal, 24 (04), 726-750. DOI: $10.1177 / 002070206902400407$

Young, O.R. (1992). The Effectiveness of International Institutions: Hard Cases and Critical Variables. In: Rosenau, J.N., Czempiel, E.-O. \& Smith, S. (Eds.). Governance without Government: Order and Change in World Politics. Cambridge, New York: Cambridge University Press. P. 160-194.

Yurtaev, V.I. (2016). BRICS: Challenges of Cooperation on the African Continent. Vestnik RUDN. International Relations, 16 (02), 191-202.

Zürn, M. (1987). Gerechte internationale Regime. Bedingungen und Restriktionen der Entstehung nichthegemonialer internationaler Regime untersucht am Beispiel der Weltkommunikationsordnung. Frankurt am Main: Haag Herchen.

Zürn, M. (1993). Problematic Social Situations and International Institutions: On the Use of Game Theory in International Politics. In: Pfetsch, F.R. (Eds.). International Relations and Pan-Europe: Theoretical Approaches and Empirical Findings. Münster: Lit-Verlag. P. 63-84.

About the author: Muntschick Johannes - PhD (Political Science), Postdoc Research Fellow and Lecturer, Department of Political Science (International Relations Unit), Johannes Gutenberg-Universität Mainz, Germany (e-mail: muntschick@uni-mainz.de).

Сведения об авторе: Мунтшик Йоханнес — кандидат политических наук, научный сотрудник и профессор департамента политической науки (секция международных отношений) Майнцского университета им. Иоганна Гутенберга, Германия (e-mail: muntschick@uni-mainz.de). 